\title{
Investigation of protective surface film behavior of fluorine containing cover gas parameters on molten magnesium alloy
}

\author{
Florin içerikli koruyucu gaz parametrelerinin ergiyik magnezyum \\ alaşımlarının yüzey filmi üzerine etkilerinin incelenmesi
}

\author{
Ali Serdar VANLI+ ${ }^{+}$iD , Anıl AKDOĞAN ${ }^{2}$ iD , Meltem ERYILDIZ ${ }^{3}$ iD \\ 1,2,3 Mechanical Engineering Department, Faculty of Mechanical Engineering ,Yildiz Technical University, Istanbul, Turkey. \\ svanli@yildiz.edu.tr, nomak@yildiz.edu.tr, mdemirci@yildiz.edu.tr
}

Received/Geliș Tarihi: 20.12.2018, Accepted/Kabul Tarihi: 05.07.2019

doi: $10.5505 /$ pajes. 2019.78026

* Corresponding author/Yazıșllan Yazar Research Article/Araștırma Makalesi

\begin{abstract}
Protection of molten magnesium is one of the most important issues for existing and potential magnesium users. An effective melt protection system is necessary for safety reasons as well as minimizing expensive metal losses. Since $\mathrm{SF}_{6}$ has an extremely high global warming potential, $H F C-134 a$ is an effective solution in many applications. In this study, surface films formed on molten AZ91A alloy under $\mathrm{HFC}-134 \mathrm{a} / \mathrm{N}_{2}$ atmosphere are examined in various parameters such as molten metal temperatures, exposure times, concentrations and flow rates of the protective gases. The obtained surface films as a result of the experiments were analyzed by optical microscope. The Taguchi experimental design method was used to determine the optimum process parameters. Process parameters provide the best protective layer on the melt; exposure time of $60 \mathrm{~min}$, molten magnesium temperature of $660{ }^{\circ} \mathrm{C}$, concentration of $0.30 \%$ vol., and the flow rate of protective gas mixture of $600 \mathrm{l} / \mathrm{h}$. were determined.
\end{abstract}

Keywords: Fluorine-containing cover gas, HFC-134a, Surface film formation, Molten magnesium protection, Taguchi robust design
Öz

Ergimiş magnezyumun korunmasl, mevcut ve potansiyel magnezyum kullanıcıları için en önemli konulardan biridir. Pahalı metal kayıplarının en az seviyeye indirilmesinin yanı sıra güvenlik gibi nedenlerinden de ötürü, etkili bir ergiyik koruma sistemi gereklidir. SF 6 , son derece yüksek bir küresel ısınma potansiyeline sahip olduğundan, HFC-134a birçok uygulamada etkili bir çözümdür. Bu çalıșmada, HFC$134 a / N_{2}$ atmosferi altında ergimiș AZ91A alașımında olușan yüzey filmleri, farklı ergimiş metal sicaklıkları, temas süreleri, konsantrasyonları ve koruyucu gaz debileri gibi çeșitli parametrelerde incelenmektedir. Optimum işlem parametrelerinin belirlenmesi için Taguchi deneysel tasarım yöntemi kullanılmıștır. Deneyler neticesinde elde edilen yüzey filmleri optik mikroskop ile analiz edilmiştir. Proses parametrelerinin ergiyik üzerinde en iyi koruyucu tabaka sağlayanları; 60 dakikalık temas süresi, $660{ }^{\circ} \mathrm{C}$ ergimiș magnezyum sıcaklığı, \% 0.30 hacimsel gaz konsantrasyon ve $600 \mathrm{l} / \mathrm{h}$ 'lik koruyucu gaz karıșim debisi olarak belirlenmiștir

Anahtar kelimeler: Florin içerikli koruyucu gaz, HFC-134a, Yüzey filmi oluşumu, Ergiyik magnezyumun korunması, Taguchi deneysel tasarım

\section{Introduction}

It is globally known that magnesium alloys shows a relatively high specific strength and good specific stiffness resulting from their low density [1]. Surface oxidation film on molten magnesium is loose and porous. This film does also not protect the magnesium melt and its alloys from oxidation. It even burns at high temperatures of melting and casting processes [2]. So that, it needs to protect the molten magnesium from oxidation. The melt requires to be protected by the use of a proper protective atmosphere even in casting and handling processes. Some remarkable studies have indicated HFC-134a contained cover gas mixtures. They mentioned that these mixtures can provide an effective protection for molten magnesium and its alloys. Recently the developed gas HFC-134a (1,1,1,2Tetrafluoroethane, $\mathrm{CF}_{3} \mathrm{CH}_{2} \mathrm{~F}$ ) is considered a good solution against $\mathrm{SF}_{6}$ contained cover gases. These studies have also mentioned about HFC-134a contented cover gas mixtures' effective protection capability for molten magnesium alloys in detail. Moreover, researchers mentioned about 18 times lower global warming potential of HFC-134a than $\mathrm{SF}_{6}$. On the contrary, the atmospheric lifetime of HFC-134a is only $0.46 \%$ of $\mathrm{SF}_{6}$ [2-6]. In literature, understanding of the mechanism of $\mathrm{SF}_{6}$, a melting technology in a sealed furnace was proposed, and the protection behavior of magnesium alloys in the sealed melting furnace was investigated under the protective atmosphere containing HFC-134a [7]. In another work, Sulphur dioxide $\left(\mathrm{SO}_{2}\right)$ mixed with carrier gases was used as an alternative to $\mathrm{SF}_{6}$ to protect molten magnesium alloys. The protection behavior of AZ91D alloy in a sealed melting furnace was investigated under the atmosphere containing $\mathrm{SO}_{2}$ with different mixed gases [8].

The aim of this experimental work is to examine the films formed on molten AZ91A alloy surface in HFC-134a/ $\mathrm{N}_{2}$ protective atmosphere at various process parameter conditions of cold chamber die casting. These parameters are different molten metal temperatures, exposure times, concentrations and flow rates of the protective gas. The Taguchi design of experiments method was used to determine the best process parameter combination against protective surface film thickness on the material, experimentally. The formed surface films on the experimental samples were analyzed by optical microscopy in detail.

\section{Experimental procedure}

The chemical composition of the material which is protected in the experiments, AZ91A magnesium alloy, is listed in Table 1. Purity of the used protective gas, HFC-134a, in the experiments was above $99.8 \%$ (by wt.).

Magnesium ingots were melted by MELTEC Industrieofenbau GmbH-Austria-MDF 200C electric resistance furnace under the mixture of HFC-134a and $\mathrm{N}_{2}$ (as a carrier gas) which was 
controlled by a mass flow meter, PGM-3000, Austria. Temperature control of molten metal is being supplied by an inert thermocouple on the furnace.

Table 1: Chemical composition of AZ91A magnesium alloy.

\begin{tabular}{ccccccccc}
\hline & $\mathrm{Mg}$ & $\mathrm{Al}$ & $\mathrm{Zn}$ & $\mathrm{Mn}$ & $\mathrm{Fe}$ & $\mathrm{Ti}$ & $\mathrm{V}$ & $\mathrm{W}$ \\
\hline$\%$ & 89.830 & 9.077 & 0.682 & 0.180 & 0.026 & 0.033 & 0.018 & 0.009 \\
\hline \pm & 0.303 & 0.297 & 0.013 & 0.014 & 0.006 & 0.008 & 0.005 & 0.003 \\
\hline
\end{tabular}

The experimental process conditions are given in the next chapter in detail. After the experiments, microscopic examinations were done to measure the formed protective film thickness on samples by a LEICA-Germany-CTR 6000 optical microscope.

\subsection{Design of experiments}

The Taguchi design of experiments method was used to determine the best process parameter combination which maximizes the protective surface film thickness on the material, experimentally. The process parameters, in other words the control factors were; molten magnesium temperature, protective gas concentration, exposure time and flow rate of the protective gas mixture in this experimental work. Film thickness was chosen as the response factor. Four factors/three levels were selected and given in Table 2. Therefore, the L9 orthogonal array was used in design stage.

Table 2: Control factor levels.

\begin{tabular}{ccccc}
\hline Symbol & Control Factor & Level 1 & Level 2 & Level 3 \\
\hline $\mathrm{A}$ & $\begin{array}{c}\text { Molten magnesium } \\
\text { temperature }\left({ }^{\circ} \mathrm{C}\right) \\
\text { Exposure time } \\
(\text { min) }\end{array}$ & 640 & 660 & 680 \\
$\mathrm{~B}$ & $\begin{array}{c}\text { Protective gas } \\
\text { concentration } \\
\quad \% \text { ) vol. }\end{array}$ & 0.20 & 0.25 & 0.30 \\
$\mathrm{C}$ & $\begin{array}{c}\text { Flow rate of the } \\
\text { protective gas } \\
\text { mixture }(\mathrm{l} / \mathrm{h})\end{array}$ & 300 & 450 & 600 \\
$\mathrm{D}$ & & & & \\
\hline
\end{tabular}

\section{Experimental results and discussions}

\subsection{Analysis of mean}

The optimal level can be determined by selecting the highest value of $\mathrm{S} / \mathrm{N}$ ratio for each factor.

The optimum combination of the levels which maximizes the protective surface film thickness is A2/B3/C3/D3, respectively; i.e. $660{ }^{\circ} \mathrm{C}$ for molten magnesium temperature, $60 \mathrm{~min}$ for exposure time, volume percent of 0.30 for the concentration of HFC-134a and $600 \mathrm{l} / \mathrm{h}$ for the flow rate of protective gas mixture. Some of the selected optical microscope images are shown in Figure 1.

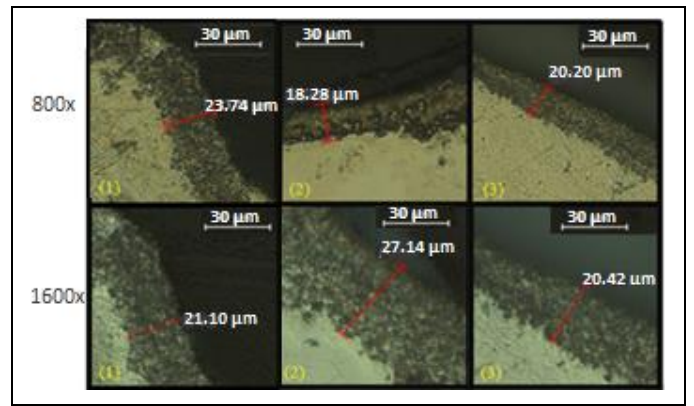

Figure 1: Optical microscope images of: (1) run 3, (2) run 6 (3) run 9.
The $\mathrm{S} / \mathrm{N}$ ratios were computed for film thickness (average of five repeated measurements) in each experimental condition and their values are given in Table 3.

Table 3: S/N Ratio for film thickness.

\begin{tabular}{ccccccc}
\hline Run & A & B & C & D & $\begin{array}{c}\text { Film Thickness } \\
(\mu \mathrm{m})\end{array}$ & $\begin{array}{c}\text { S/N Ratio } \\
(\mathrm{dB})\end{array}$ \\
\hline 1 & 1 & 1 & 1 & 1 & 6.01 & 15.571 \\
2 & 1 & 2 & 2 & 2 & 14.61 & 23.293 \\
3 & 1 & 3 & 3 & 3 & 23.31 & 27.352 \\
4 & 2 & 1 & 2 & 3 & 9.26 & 19.334 \\
5 & 2 & 2 & 3 & 1 & 21.36 & 26.592 \\
6 & 2 & 3 & 1 & 2 & 26.89 & 28.591 \\
7 & 3 & 1 & 3 & 2 & 10.56 & 20.469 \\
8 & 3 & 2 & 1 & 3 & 20.31 & 26.154 \\
9 & 3 & 3 & 2 & 1 & 23.11 & 27.276 \\
\hline
\end{tabular}

Figure 2 shows the effects of the four control factors (molten magnesium temperature, exposure time, protective gas concentration, flow rate of the protective gas mixture) on the mean of $\mathrm{S} / \mathrm{N}$ ratios, respectively.

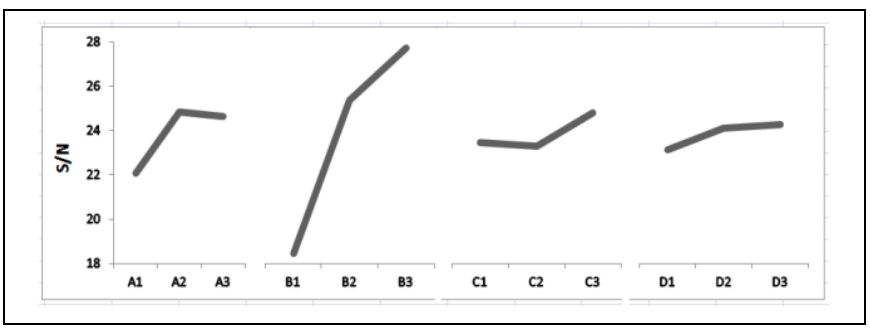

Figure 2: Effect of control factors on film thickness via S/N ratio.

Based on the calculated signal to noise $(\mathrm{S} / \mathrm{N})$ ratio, according to "larger is the better approach", optimum process parameters are determined as A2/B3/C3/D3 from Figure 2. The optimal settings of process parameters are exposure time of $60 \mathrm{~min}$, molten magnesium temperature of $660{ }^{\circ} \mathrm{C}$, concentration of $0.30 \%$ vol. and the flow rate of protective gas mixture of $600 \mathrm{l} / \mathrm{h}$.

\subsection{Analysis of Variance (ANOVA)}

The contribution of each factor to the surface film thickness is calculated in a statistical analysis program by ANOVA.

The results are summarized in Table 4. It is evident that, among all these selected factors; exposure time is found as the most effective factor on the formation of the surface film.

Table 4: ANOVA test results.

\begin{tabular}{|c|c|c|c|c|c|}
\hline Symbol & Factors & DF & Seq SS & Adj MS & Variance (\%) \\
\hline A & $\begin{array}{c}\text { Molten } \\
\text { magnesium } \\
\text { temperature } \\
\left({ }^{\circ} \mathrm{C}\right)\end{array}$ & 2 & 33.092 & 16.546 & 7.655 \\
\hline B & $\begin{array}{l}\text { Exposure time } \\
\text { (min) }\end{array}$ & 2 & 385.874 & 192.937 & 89.265 \\
\hline $\mathrm{C}$ & $\begin{array}{c}\text { Protective gas } \\
\text { concentration } \\
\text { (\%) vol. }\end{array}$ & 2 & 12.313 & 6.156 & 1.249 \\
\hline $\mathrm{D}$ & $\begin{array}{l}\text { Flow rate of } \\
\text { the protective } \\
\text { gas mixture } \\
(1 / \mathrm{h})\end{array}$ & 2 & 0.988 & 0.499 & 0.228 \\
\hline Error & & 0 & 0 & 0 & \\
\hline Total & & 8 & 432.278 & 0 & \\
\hline
\end{tabular}




\subsection{Confirmation test}

The confirmation test was run by the resulted optimum process parameter combination as A2/B3/C3/D3. The results indicated that the new process's film thickness was $26.12 \mu \mathrm{m}$ with an $\mathrm{S} / \mathrm{N}$ value of 28.34. These values represent an improvement over the experimental results, and this verification test enhances confidence in the technique. Figure 3 gives optical images of confirmation run results.

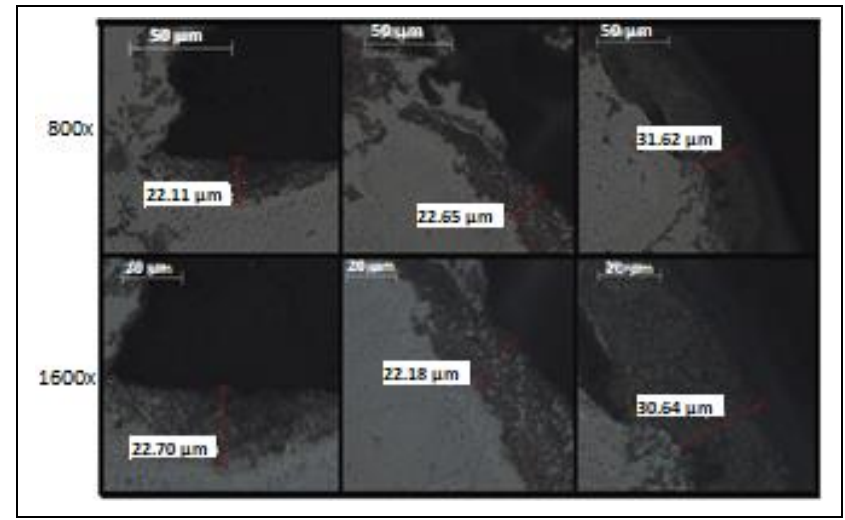

Figure 3: Optical microscope images of confirmation run.

\subsection{Development of regression model}

The least square linear regression model is used to determine a regression model between the surface film thickness and the process parameters. The equation is calculated by the mean values of surface film thickness according to different operating conditions. As $\mathrm{T}$ denotes the surface film thickness, the obtained equation is given in equation [1].

$$
\begin{gathered}
T=-49.888+0.084 * A+0.285 * B+6.75 * C \\
+0.003 * D
\end{gathered}
$$

The regression statistics were also calculated by the Minitab 16.0 program and the results are given in Table 5. The multiple $\mathrm{R}$ is 0.895 . It indicates that the regression model could explaine more than $89.5 \%$ of the variability of the surface film thickness against process parameters ( $\mathrm{R}-\mathrm{Sq}$ is $89.50 \%, \mathrm{R}-\mathrm{Sq}(\mathrm{adj})$ is $79.01 \%$ and $\mathrm{R}-\mathrm{Sq}$ (pred) is $41.34 \%$ ). There is an $89.5 \%$ chance that a "Lack of Fit F-value" could occur due to noise.

\section{Conclusion}

The optimum process parameters are determined as A2/B3/C3/D3 according to the calculated signal to noise $(\mathrm{S} / \mathrm{N})$ ratio which is denoted by "larger is the better approach. The optimal settings of process parameters are the exposure time of $60 \mathrm{~min}$, the molten magnesium temperature of $660{ }^{\circ} \mathrm{C}$, the concentration of $0.30 \%$ vol., and the protective gas mixture flow rate as $600 \mathrm{l} / \mathrm{h}$. They supplied the maximum surface film thickness in the experiments. The conducted ANOVA test results indicate that the exposure time has the major effect on surface film thickness. The molten magnesium temperature, the gas concentration and the protective gas flow rate have minor effects on it, respectively. The developed regression model on surface film thickness against the process parameters is almost $80 \%$ (adj.) confidential.

\begin{tabular}{|c|c|c|c|c|c|c|c|}
\hline Symbol & Factors & Seq SS & DF & Adj SS & Adj Ms & $\mathrm{F}$ & $\begin{array}{c}\mathrm{P}- \\
\text { value }\end{array}$ \\
\hline & Regression & 386.902 & 4 & 386.902 & 96.726 & 8.527 & 0.031 \\
\hline A & $\begin{array}{c}\text { Molten } \\
\text { magnesium } \\
\text { temperature } \\
\left({ }^{\circ} \mathrm{C}\right)\end{array}$ & 16.820 & 1 & 16.820 & 16.820 & 1.483 & 0.290 \\
\hline B & $\begin{array}{l}\text { Exposure time } \\
\text { (min) }\end{array}$ & 368.431 & 1 & 368.431 & 368.431 & 32.478 & 0.0047 \\
\hline C & $\begin{array}{c}\text { Protective gas } \\
\text { concentration } \\
\text { (\%) vol. }\end{array}$ & 0.684 & 1 & 0.684 & 0.684 & 0.060 & 0.818 \\
\hline \multirow[t]{4}{*}{ D } & $\begin{array}{c}\text { Flow rate of } \\
\text { the protective } \\
\text { gas mixture } \\
(1 / \mathrm{h})\end{array}$ & 0.967 & 1 & 0.967 & 0.967 & 0.085 & 0.785 \\
\hline & Error & 45.376 & 4 & 45.376 & 11.344 & & \\
\hline & Total & 432.278 & 8 & & & & \\
\hline & PRESS & 253.554 & & & & & \\
\hline
\end{tabular}

Table 5: ANOVA test results.

\section{References}

[1] Mathis K, Zdražilova Z, Farkas G, Trojanova Z, Lukač P, Vidrich G. "Effect of temperature on mechanical properties of continuously cast AZ31 magnesium alloy". Kovove Mater., 50, 139-143, 2012.

[2] Liu JR, Chen HK, Zhao L, Huang WD. “Oxidation behavior of molten magnesium and AZ91D magnesium alloy in 1,1,1,2-tetrafluoroethane/air Atmospheres". Corrosion Science, 51, 129-134, 2009.

[3] Zhao L, Liu JR, Chen HK, Huang WD. "The Characterization of Surface Films Formed on Molten Magnesium and AZ91D Alloy in air/1,1,1,2-tetrafluoroethane Atmospheres". Journal of Alloys and Compounds, 480, 711-716, 2009.

[4] Chen H, Liu J, Huang W. "The protective surface film formed on molten ZK60 magnesium alloy in 1,1,1,2tetrafluoroethane/air atmospheres". Corrosion Science, 52, 3639-3645, 2010.

[5] Ha W, Kim Y. "Effects of cover gases on melt protection of $\mathrm{Mg}$ alloys". Journal of Alloys and Compounds, 422, 208-213, 2006.

[6] Mirak A, Davidson CJ, Taylor JA. "Characterization of fresh surface oxidation films formed on pure molten magnesium in different atmospheres". Corrosion Science, 52, 1992-2000, 2010.

[7] Wang X., Xiong S. "Protection behavior of $\mathrm{SO}_{2}$-containing cover gases to molten magnesium alloy". Transactions of Nonferrous Metals Society of China, 21(4), 807-813, 2011.

[8] Xiong S, Wang X. "Protection behavior of fluorinecontaining cover gases on molten magnesium alloys". Transactions of Nonferrous Metals Society of China, 20(7), 807-813, 2010. 